\title{
Güneş Paneli ve Yakıt Pili Karma Temiz Enerji Sisteminde Beş Seviyeli BMD’li STATCOM
}

\author{
$\underline{\text { Kenan YANMAZ }}^{1}$, Onur Özdal MENGİ ${ }^{2}$ İsmail Hakkı ALTAȘ ${ }^{3}$ \\ ${ }^{1}$ Giresun Üniversitesi, Teknik Bilimler MYO, Elektronik ve Otomasyon Bölümü, Giresun, TÜRKIYE \\ ${ }^{2}$ Giresun Üniversitesi, Mühendislik Fak, Enerji Sistemleri Mühendisliği Bölümü, Giresun, TÜRKIYYE \\ ${ }^{3}$ Karadeniz Teknik Üniversitesi, Mühendislik Fak, Elektrik Elektronik Mühendisliği, Trabzon, TÜRKIYE
}

Sorumlu Yazar: kenan.yanmaz@giresun.edu.tr

Geliş Tarihi: 15.11 .2016

Kabul Tarihi: 05.12.2016

\begin{abstract}
Özet
Bu makalede Güneş Panelleri (GP) ve Yakıt Pillerinden (YP) oluşan karma yenilenebilir enerji üretim sistemi için 5 seviyeli Statik Senkron Kompanzatör (STATCOM)'un benzetim çalışması yapılmıştır. Güneş panellerinin yetersiz güneş 1şı̆̆ı ve gündüz-gece durumu gibi ortam şartlarından dolayı güç üretemediği durumlarda yüklerin enerjisiz kalmasını önleyebilmek için hidrojen ile çalışan PEM tipi yakıt pilleri konmuştur. Bunun için iki sistem arasında geçişi sağlayan bir adet regülatör kullanılmıştır. Bu sistem ortam şartlarına göre uygun üreteci devreye alırken diğerini de devreden çıkartmaktadır. Kurulan sistem yükler üzerindeki reaktif gücü sıfırladığı gibi aynı zamanda yük üzerindeki gerilimi de $380 \mathrm{~V}$ ve $50 \mathrm{~Hz}$ de sabit tutmaktadır. Şebekeden çekilen reaktif güç STATCOM vasıtasıyla sıfırlanmaktadır. STATCOM 5 seviyeli H köprü temelli 24 IGBT'den oluşan bir evirici yapısına sahiptir. Bu IGBT'ler Bulanık Mantık Denetleyiciler (BMD) ile denetlenmekte ve anahtarlama sinyalleri üretilmektedir. Benzetim çalışması alt blokları ile birlikte MATLAB/Simulink ortamında gerçekleştirilmiştir.
\end{abstract}

Anahtar kelimler: Güneş Paneli, Yakıt Pili, STATCOM, BMD, beş seviyeli evirici.

\section{Five Level BMD STATCOM in the Solar Panel / Fuel Cell Hybrid Clean Energy System}

\begin{abstract}
In this article, a 5-level Static Synchronous Compensator (STATCOM) simulation study was conducted for a hibrid renewable energy system consisting of Solar Panels (SP) and Fuel Cells (FC). A hydrogenpowered PEM fuel cell is installed to prevent loads from being de-energized when SP cannot generate power due to ambient conditions such as inadequate sunlight and day-night conditions. To do this, one regulator is used to provide a transition between the two systems. This system deactivates the other generator while the appropriate generator is activated according to the ambient conditions. The installed system eliminates the reactive power on the loads and at the same time keeps the voltage on the load at $380 \mathrm{~V}$ and $50 \mathrm{~Hz}$. Reactive power flow loaded from the grid is reseted by STATCOM. The structure of STATCOM has an inverter consisting of 5 levels of $\mathrm{H}$ bridge 24 IGBTs. These IGBTs are controlled by Fuzzy Logic Controllers (FLC) and switching signals are generated. Simulation work was performed in MATLAB / Simulink environment with sub blocks.
\end{abstract}

Keywords: Solar Panel, Fuel Cell, STATCOM, Fuzzy Logic Controller, Five level inverter. 


\section{Giriş}

Güneş enerjisi tükenmeyen yani hiçbir zaman bitmeyecek olan yenilenebilir enerji kaynaklarından birisi olduğu gibi petrol ve doğalgaz gibi diğer kaynaklardan farklı olarak da çevreye herhangi bir zararı olmayan temiz bir enerji kaynağıdır. Sınırsız ve temiz bir enerji olması ve çevreye olan duyarlılığı nedenleriyle son yıllarda en çok tercih edilen gözde kaynaklardan birisi olmayı başarmıştır. Yıllar geçtikçe daha düşük maliyetli ve yüksek verimli olarak geliştirilmeye devam edilmektedir.

Güneş enerjisinden elektrik elde etmek için fotovoltaik güneş panelleri kullanılır. Güneş panelleri yapısında güneş enerjisini soğurarak güneş ışığını elektrik enerjisine çeviren güneş hücreleri bulunur. Bu hücrelerin üzerine güneş 1ş1kları isabet ettiğinde güneş paneli hücreleri tarafından doğru akım üretilir. Üretilen bu elektrik enerjisi de akü gruplarında depolanır (Quasching, 2005).

Yakıt pilleri de güneş panelleri gibi önemli yenilenebilir enerji kaynaklarından birisi olmasına rağmen güneş enerjisi kadar yaygın olarak kullanılmamaktadır. Yakıttaki kimyasal enerjiyi doğrudan elektrik enerjisine çeviren sistemlerdir. Havadaki oksijen ile yapısındaki hidrojen sayesinde reaksiyona girer ve bu yakıt pili reaksiyonu sayesinde doğru akım üretilir.

GP ile YP kaynaklarının birlikte kullanılması durumunda birbirlerini tamamlayarak daha verimli ve kesintisiz bir enerji sağlamak mümkün olmaktadır.

\section{Materyal ve Metodlar}

GP/YP karma enerji sistemlerinde diğer tüm enerji sistemlerinde olduğu gibi kompanzasyon ihtiyacı vardır. Kompanzasyon sistemleri için son yıllarda sıklıkla kullanılmaya başlanan sistemlerden birisi de STATCOM cihazıdır. STATCOM alternatif akım sistemlerinde güç kalitesi iyileştirici, sistemlere paralel bağlanan, evirici tabanlı bir FACTS cihazıdır. Benzetimi yapılan Şekil 1'de görülen sistemde reaktif güç kompanzasyonu için sisteme paralel bağlı beş seviyeli H-köprü evirici tabanlı STATCOM kullanılmıştır. Şekil 1'de görülen sistemin ana yapısında GP ile YP enerji sistemleri bir DA bara yardımıyla bir noktada birleştirilir. Bu DA baranın çıkışında elde edilen gerilim bir evirici aracılığıyla AA gerilime dönüştürülür. Elde edilen sistem gerilimi ile yükler beslenir. Sistemdeki istenmeyen reaktif güçler, yüklere paralel olarak 
bağlanan STATCOM cihazı ile elimine edilir. Böylece kompanzasyon gerçekleştirilmiş olur.

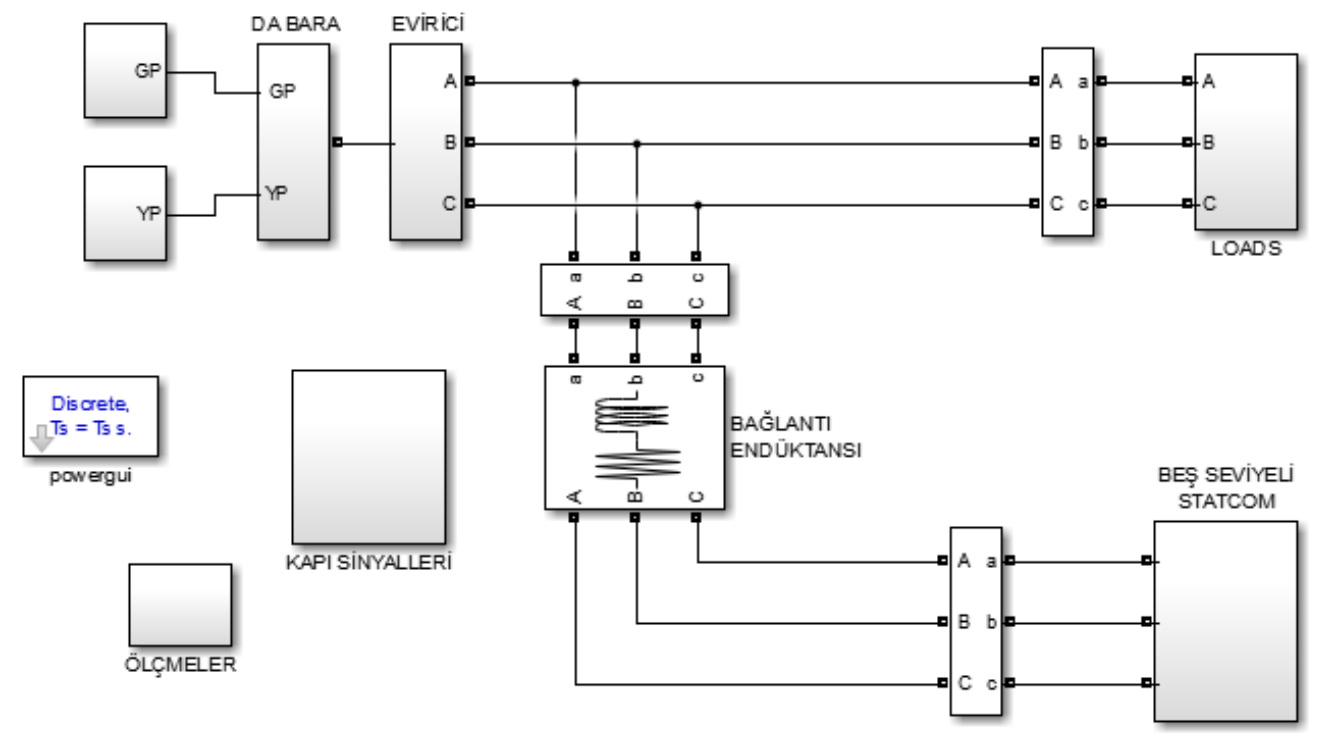

Şekil 1. Sistemin temel yapısının Matlab/Simulink modeli.

\section{GP Sistemi}

Güneş pilinin eşdeğer devresi Şekil 2'de görülmektedir. Güneş pili eşdeğer devresi bir akım kaynağına ters paralel bir diyot ve çıkışa seri bağlı bir dirençten oluşmaktadır. Elde edilen güç güneş ışıma düzeyi ve ortam sıcaklığına bağlı olarak değişmektedir.

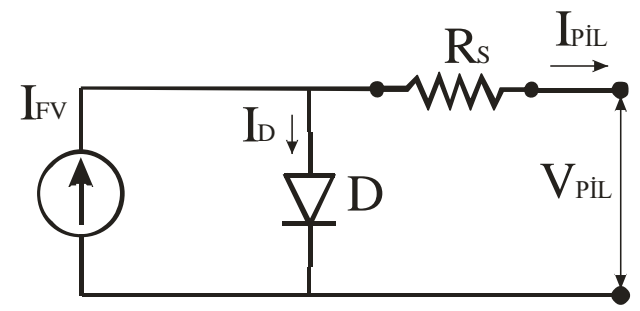

Şekil 2. GP sistemi güneş pilinin eşdeğer devresi.

Matlab/Simulink ortamı için geliştirilen modelin temel başlangıç noktası Şekil 2'de gösterilen devrede GP sisteminin çıkış gerilimini ifade eden (1) denklemidir. 
$\mathrm{V}_{\mathrm{pil}}=\frac{\mathrm{A} \times \mathrm{k} \times \mathrm{T}_{\mathrm{pil}}}{\mathrm{e}} \ln \left(\frac{\mathrm{I}_{\mathrm{ph}}+\mathrm{I}_{0}-\mathrm{I}_{\mathrm{pil}}}{\mathrm{I}_{0}}\right)-\mathrm{R}_{\mathrm{S}} \times \mathrm{I}_{\mathrm{pil}}$

Burada; Ipil: FV pilin çıkış akımı (A), Vpil :FV pilin çıkış gerilimi (V), Iph :Işık seviyesi ve P-N birleşim noktası, sıcaklığının fonksiyonu, Fotoakım (5A), I0: diyot ters doyma akımı (0.0002A), RS: Eşdeğer devrenin seri direnci $(0.0001 \Omega)$, e: Elektron yükü (1.6021917x10-19C), k: Boltzmann sabiti (1.380622x10-23 J/oK), Tpil: Referans çalışma sıcaklığı (25oC), A: Eğri uydurma faktörü (100).

GP model için parametreler Tablo 1'de verilmektedir.

Tablo 1. GP güneş hücrelerinin sabitleri.

\begin{tabular}{|lll|lll|l|}
\hline $\mathbf{T}_{\mathrm{a}}$ & $:$ & $25^{\circ} \mathrm{C}$ & $\boldsymbol{\beta}_{\mathrm{T}}$ & $:$ & 0.005 & $\boldsymbol{\alpha}_{\mathrm{S}}: 0.3$ \\
\hline $\mathbf{S}_{\mathrm{pil}}$ & $:$ & $100 \mathrm{~mW} / \mathrm{cm}^{2}$ & $\boldsymbol{\gamma}_{\mathrm{T}}$ & $:$ & 0.02 & \\
\hline
\end{tabular}

Güneş panelleri değişik şekillerde bağlanabildiği gibi seri ya da paralel şekillerde de bağlanabilmektedir (Mengi ve Altaş, 2008).

\section{YP Sistemi}

Bir yakıt pilinin temel yapısı Şekil 3'te görüldüğü gibi bir elektrolit gibi görev yapan katı bir zar (membran) tarafından ayrılmış iki elektrot (anot ve katot) olarak tanımlanabilir.

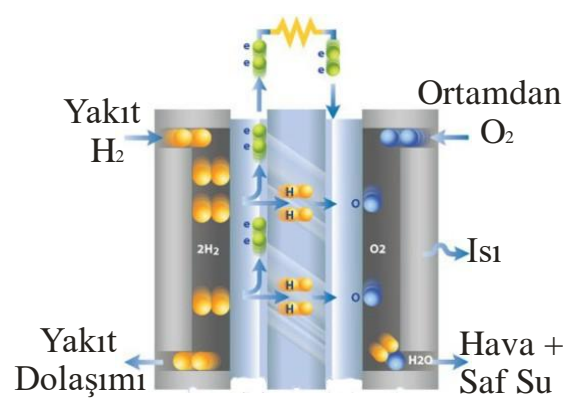

Şekil 3. Yakıt pilinin şematik görünümü.

Hidrojen yakıtı anoda protonlara ayrıştığı yer olan bir kanal içinden geçer. Ayrışan protonlar katoda membran içinden ulaşır. Bir dış devre tarafından elektriksel akım olarak toplanan elektronlar iki elektrotu birbirine bağlar. Benzer bir kanal ağı 
içinden hava, bir dış devrede elektronlarla birlikte oksijenin toplandığg yer olan katoda, protonlarda membran içine doğru akar ve böylece su oluşur. Bir yakıt pilinin anot ve katot elektrotlarında meydana gelen kimyasal reaksiyonlar Şekil 3 'te verildiği gibidir. Polimer membran iki elektrot arasına sıkıştırılmıştır. Her bir elektrot bir gaz difüzyon tabakası ve bir ince katalizör tabakadan oluşmaktadır. Membran-elektrot bileşkesi reaktant akışına izin veren kanallarını kapsayan iki iletken tabaka tarafından sıkıştırılmıştır. Anottan gelen hidrojen ile katottan gelen oksijen 1sı ve su üretmek için birleşir. Toplam hücre reaksiyonu Denklem (2)'de verildiği gibidir.

$2 \mathrm{H}_{2}+\mathrm{O}_{2} \rightarrow 2 \mathrm{H}_{2} \mathrm{O}+1 \mathrm{~S} 1$

\section{STATCOM}

STATCOM, AC sistem geriliminden bağımsız olarak denetimi yapılabilen paralel bağlı bir statik senkron kompanzatördür. STATCOM'un hızlı cevap zamanına sahip olması, daha az yer gereksiniminin olması, yüksek işletme esnekliğine ve farklı çalışma şartları altında çok iyi bir dinamik karakteristiğe sahip olması gibi önemli özellikleri vardır (Singh ve ark., 2009). Statik Senkron Kompanzatör, şebeke frekansında bağlı olduğu sisteme sürekli olarak hem endüktif hem de kapasitif reaktif güç veren ya da sistemden reaktif güç çeken bir FACTS cihazıdır.

Genel itibariyle güç kalitesi iyileştirici bir cihaz olarak tanımlanan STATCOM'un temel yapısı Şekil 4’te görülmektedir.
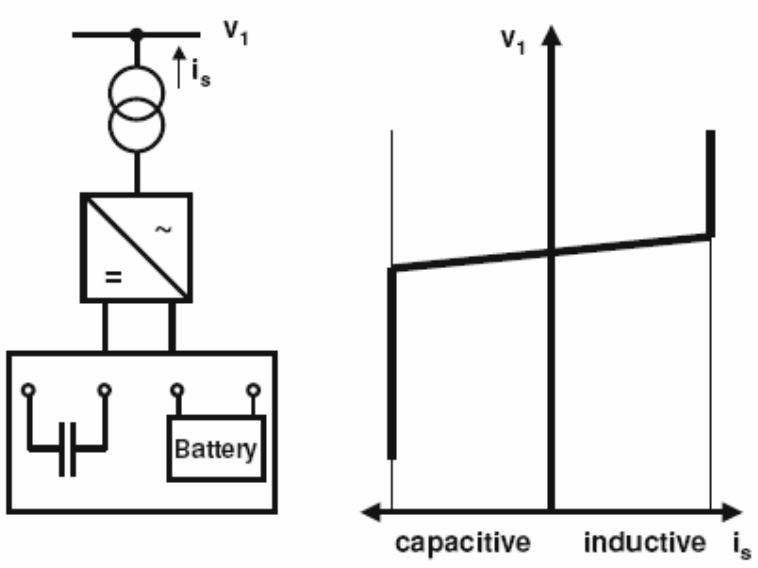

Şekil 4. STATCOM'un yapısı. 
Şekil 4'te görüldüğü gibi STATCOM cihazının yapısında bir adet üç fazlı gerilim kaynaklı dönüştürücü, anahtarlama sinyalleri için denetleyici, DA kondansatörü ve bir bağlantı endüktansı ya da bağlantı transformatörü bulunmaktadır. Uygun anahtarlama sinyalleri ile evirici yapısında bulunan IGBT'ler kontrol edilerek kondansatörler devreye alınmakta ve devreden çıkarılmaktadır. Burada anahtarlama sinyallerinin genişliği için Sinüzoidal Darbe Genişlik Modülasyonu (SDGM) tekniği kullanılmıştır. 24 IGBT'den oluşan sistem 5 seviyeli bir evirici yapısıdır (Gultekin ve Ermis, 2013). Yüklerden ve sistemden kaynaklanan reaktif güç STATCOM cihazı kullanılarak elimine edilmektedir (Hingorani ve Gyugyi, 2000).

\section{$B M D$}

Bulanık mantık denetleyicinin genel akış diyagramı Şekil 5'te görülmektedir. Denetleyici 3 parçadan oluşmaktadır. Bunlar sırasıyla, Bulanıklaştırıcı, Kural Tabanı ve Durulaştırıcıdır. BMD’nin ilk elemanı olan Bulanıklaştırıcı kendisine uygulanan kesin girişleri bulanık değerlere çevirir. $\mathrm{Bu}$ bulanık değerler Kural Tabanı ünitesine gönderilerek burada bulanık kurallarla işlenir ve elde edilen bulanık sonuç Durulaştırma ünitesine gönderilir. Bu kısımda ise bulanık sonuçlar kesin sayıya dönüştürülür (Ross, 2004; Altaş ve Sharaf, 2007).

Bulanık Mantık Denetleyici

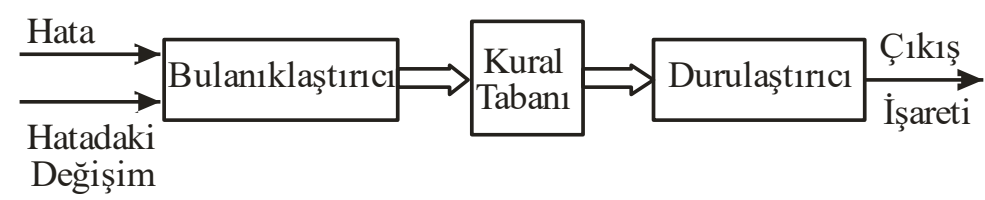

Şekil 5. BMD’nin temel yapısı.

Bu çalışma için Şekil 6' da görülen üçgen üyelik fonksiyonu tercih edilmiştir. 


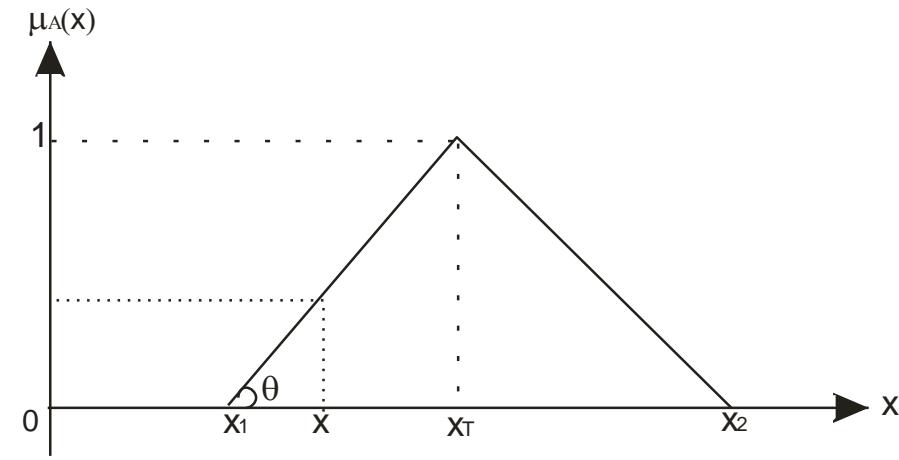

Şekil 6. BMD için üçgen üyelik fonksiyonu.

Üçgen üyelik fonksiyonundan elde edilen bulanık değerler ise denklem (3) kullanılarak hesaplanmaktadır.

$\mu_{\mathrm{AÜ}}(\mathrm{x})=\max \left(\min \left(\frac{\mathrm{x}-\mathrm{x}_{1}}{\mathrm{x}_{\mathrm{T}}-\mathrm{x}_{1}}, \frac{\mathrm{x}_{2}-\mathrm{x}_{1}}{\mathrm{x}_{2}-\mathrm{x}_{\mathrm{T}}}\right), 0\right)$

Giriş uzayından gelen üyelik değerlerinin minimumları alınarak her kural için gerekli ağırlık katsayıları belirlenir. Gerekli ağırlık katsayıları bulanıklaştırma ünitesinde belirlendikten sonra bu değerler çarpılmak üzere kuralların işlendiği kısma gönderilir. Durulaştırma ünitesinde alanların merkezi yöntemi kullanılarak kesin değerler elde edilir. Bu kesin değerler denetleyicinin çıkışıdır (Mengi ve Altaş, 2012).

STATCOM kontrolü için kullanılan dolaylı akım denetim yönteminde DA gerilimi sabit tutularak eviricinin üretmesi gereken referans gerilimler üretilir. $\mathrm{Bu}$ yap1 Şekil 7'de görülmektedir.

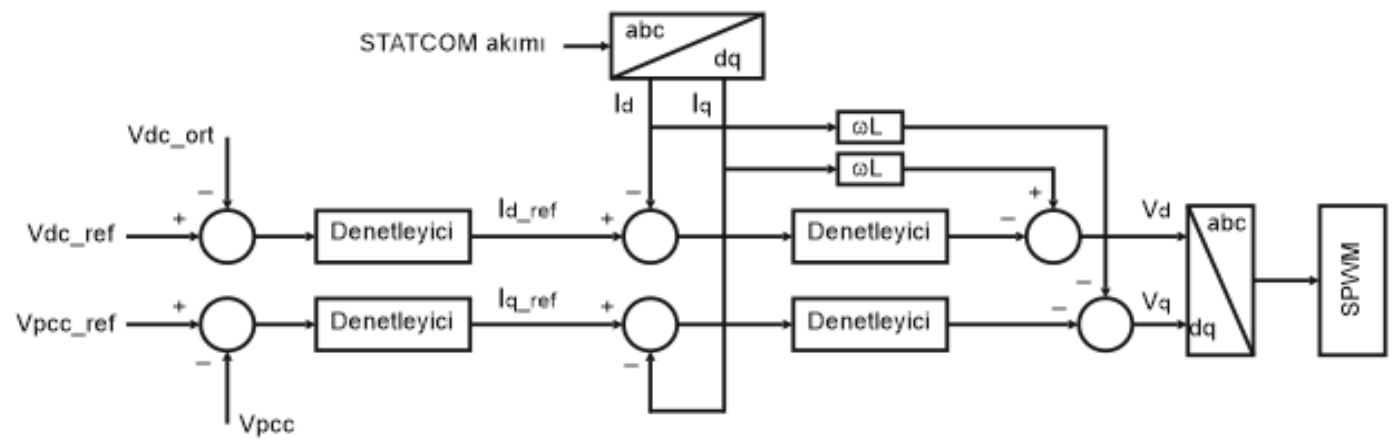

Şekil 7. Dolaylı akım denetim yöntemi blok diyagramı. 
STATCOM yapısında bulunan kondansatör gerilimini kontrol edilmesiyle dolaylı olarak reaktif çıkış akımının denetimi yapılmış olunur. Bu denetim sırasında da denetleyici olarak BMD kullanılmaktadır.

\section{Sonuçlar ve Tartışma}

Yapılan benzetim çalışmasında kaynak olarak güneş panelleri ve yakıt pillerinden oluşan karma enerji sistemi kullanılmıştır. Bu kaynaktan elde edilen enerji yüklere aktarılmaktadır. Kaynak ile yükler arasına paralel olarak STATCOM cihazı yerleştirilmiştir. Kullanılan GP sisteminde 40 adet güneş paneli seri ve 20 paralel koldan oluşmaktadır. Toplam 800 adet güneş paneli bulunmaktadır. Her biri 100Wp güç değerine sahiptir. Kurulu gücü $80 \mathrm{~kW}$ 'dır. YP sistemi GP sistemine destek amaçlı kullanılmıştır. Güneş olmadığı durumda ya da yeterli gelmediği zaman devreye girerek yüklerin ihtiyaç duyduğu gücü sağlamaktadır. Burada da 5 adet 160V/100A'lik YP birbirine seri bağlanarak $800 \mathrm{~V} / 100 \mathrm{~A}$, toplam $80 \mathrm{~kW}$ 'l1k bir sistem kurulmuştur. Çalışmada $12 \mathrm{~kW} / 8 \mathrm{kVAr}$ 'lık bir RL yükü ile birlikte $25 \mathrm{~kW}$ 'lık bir direnç yükü kullanılmıştır. Kullanılan STATCOM 100kVAr'lık bir güç değerine sahiptir ve bir bağlantı endüktansı yardımı ile sisteme bağlanmaktadır. STATCOM cihazında kullanılan beş seviyeli eviricide BMD tabanlı bir denetleyici kullanılmaktadır ve gereken IGBT sinyalleri bu şekilde üretilmektedir. Benzer şekilde yükler üzerindeki gerilim değeri de $380 \mathrm{~V} / 50 \mathrm{~Hz}$ değerine bir BMD ile ayarlanmaktadır. Ayrıca sistemde GP ve YP arasında ortama uygun olacak şekilde gereken enerji üretim sistemini devreye alıp çıkaran bir regülatör ve ölçü aletleri de kullanılmıştır.

Hem STATCOM'un devrede olduğu durumlar için hem de STATCOM'un devrede olmadığı durumlar için ayrı ayrı benzetim çalışması yapılmış ve sonuçları kıyaslanmıştır. Her iki durumda da güneş panellerinin Sx ve Tx değişimleri Şekil 8'de ve Şekil 9'da görülmektedir. 


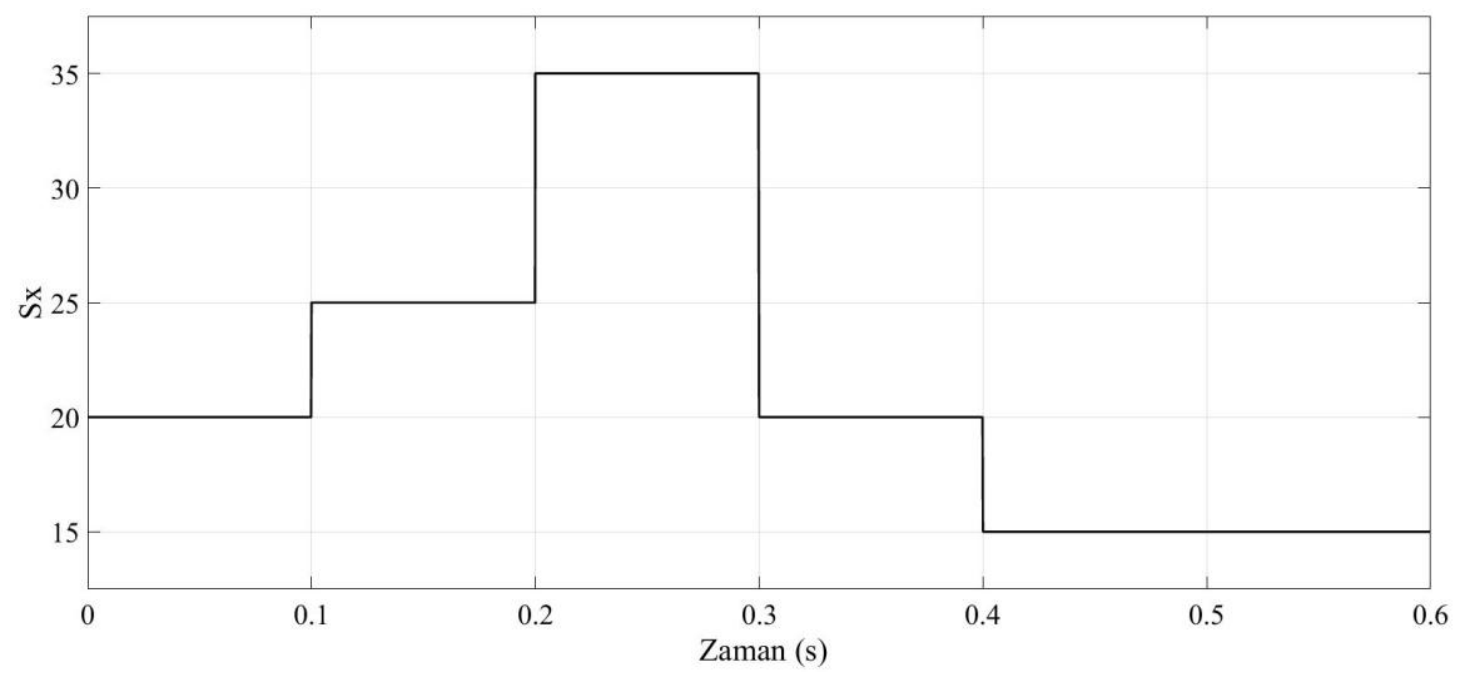

Şekil 8. Güneş panellerindeki 1şık seviyesinin değişimi Sx.

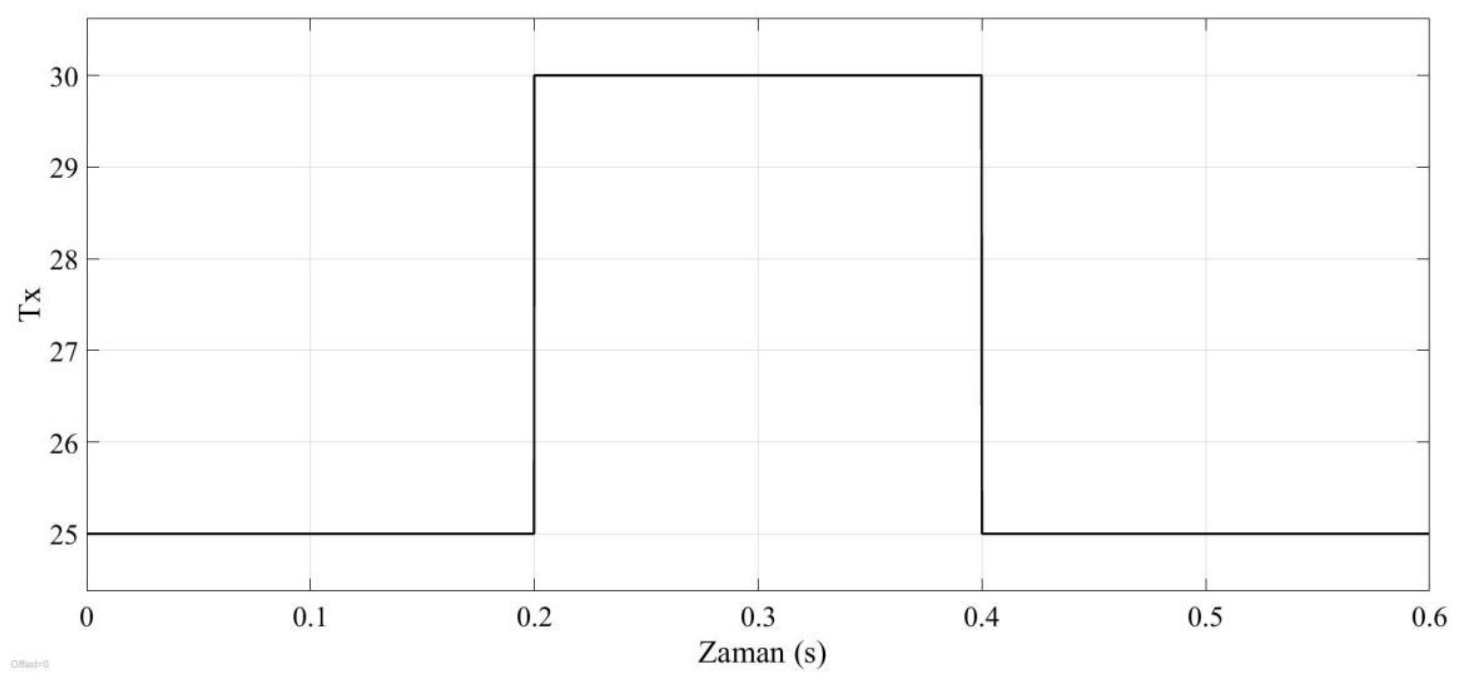

Şekil 9. Güneş panellerinin bulunduğu ortam sıcaklığının değişimi Tx.

Şekil 10'da ve Şekil 11'de ortak bağlantı noktasındaki akım ve gerilim değişimleri görülmektedir. STATCOM'un devrede olmadığı durum için sistemin ortak bağlantı noktasında ölçülen akım ve gerilim arasında faz farkı bulunmaktadır ve dalga şekilleri bozuktur. 


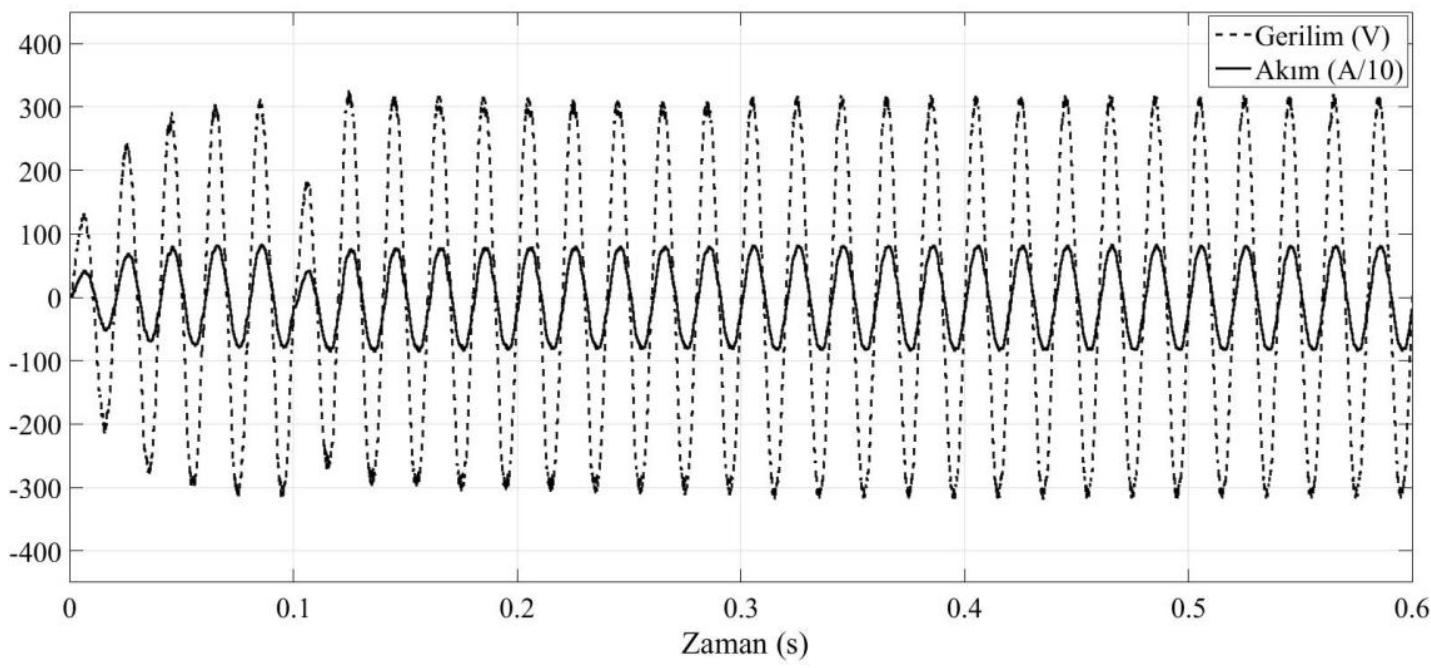

Şekil 10. Ortak bağlantı noktası akım ve gerilim değişimi.

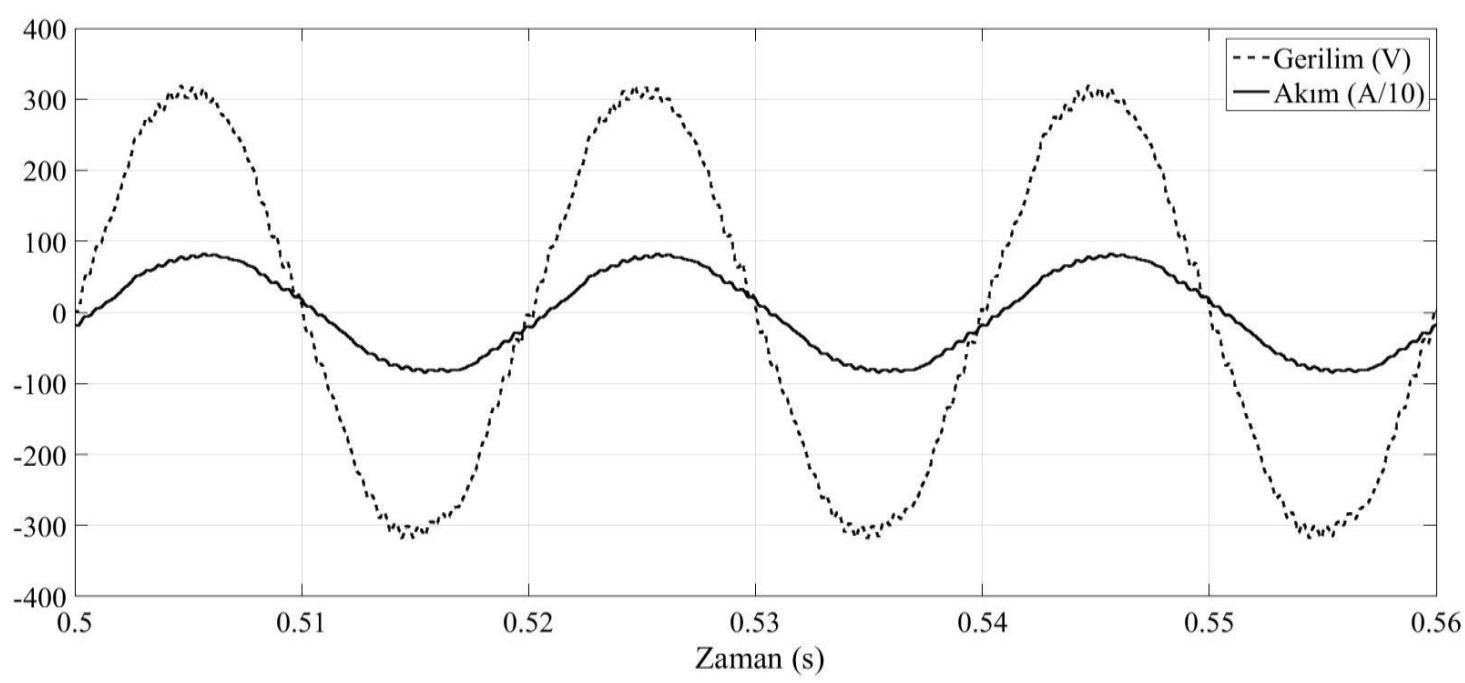

Şekil 11. Ortak bağlantı noktası akım ve gerilim değişiminin ayrıntılı gösterimi.

Şekil 12'de aktif ve reaktif güçlerin değişimleri görülmektedir. Dalgalanmaların olduğu bölümlerde ya güneş panellerinden yakıt piline ya da yakıt pilinden güneş panellerine değişimin olduğu yerlerdir. Toplam $37 \mathrm{~kW}$ 'llk omik yük ve $8 \mathrm{kVAr}$ 'lık reaktif güç bulunmaktadır. 


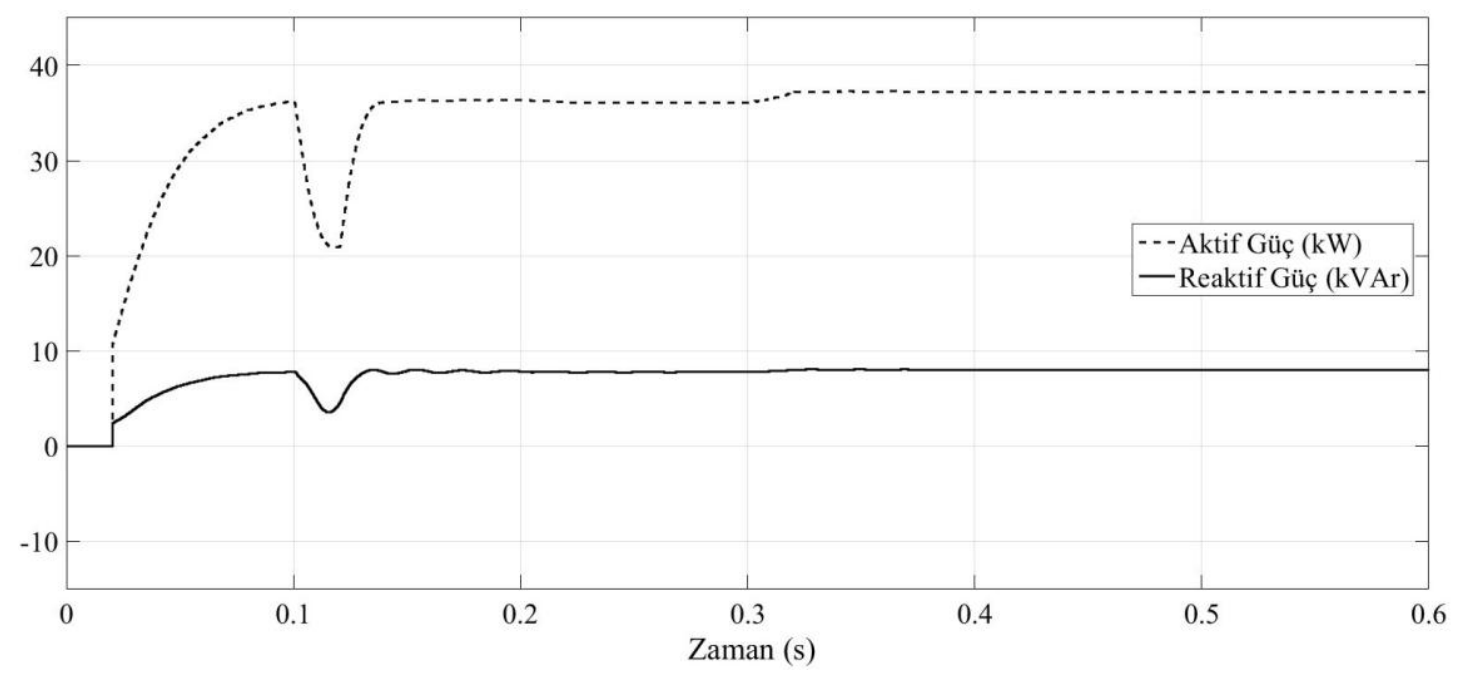

Şekil 12. Ortak bağlantı noktası aktif ve reaktif güç değişimleri.

STATCOM'un devreye alınması durumunda ise Şekil 13'te güneş panelinin ortam şartlarının elvermesi durumunda devreye girip çıktığı zaman aralıkları ve buna bağlı olarak güneş panelleri sisteminden çekilen akım, gerilim ve güç değerleri görülmektedir. Sistem 0,1-0,3 sn zaman aralığında devrededir.
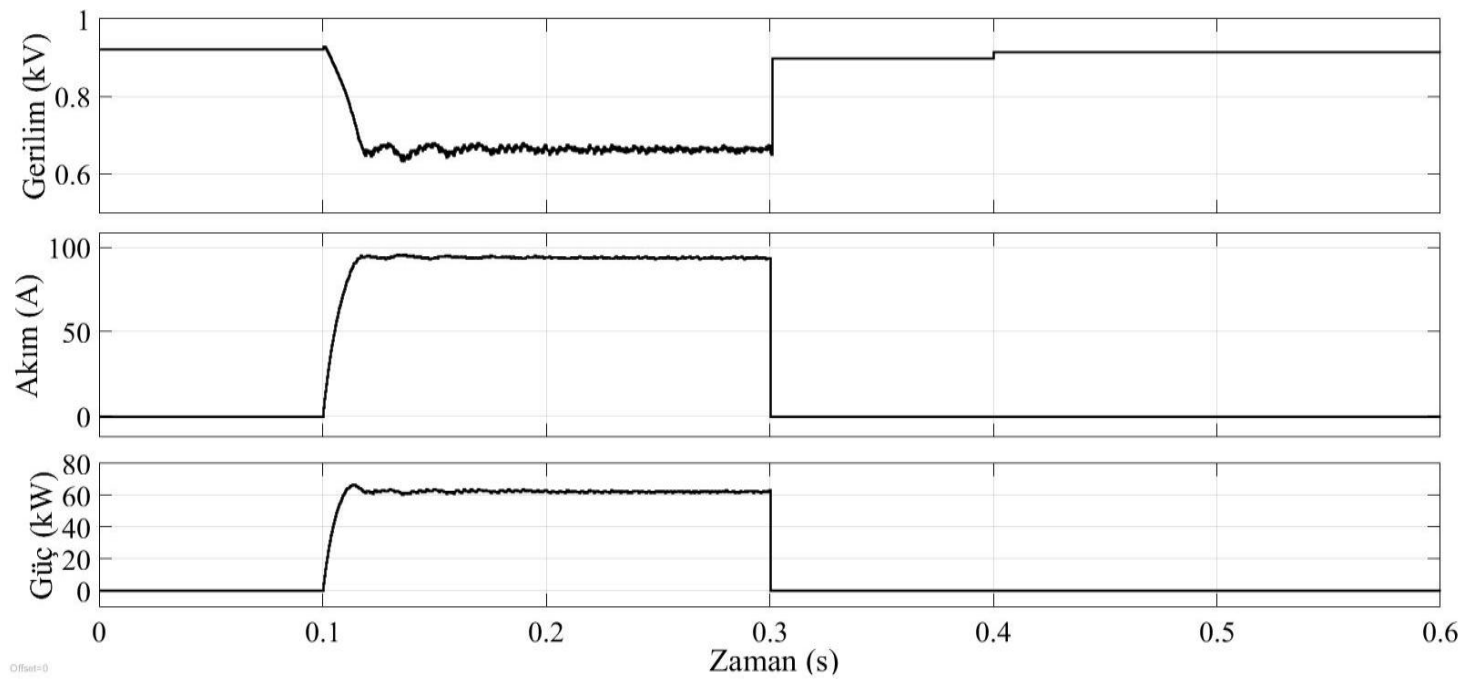

Şekil 13. Güneş panellerine ait akım, gerilim ve güç değişimleri.

Şekil 14'te yakıt pillerinin devreye girip çıktığı zaman aralıkları ve buna bağlı olarak bu sisteminden çekilen akım, gerilim ve güç değerleri görülmektedir. Sistem 00,1 sn ve 0,3-0,6 sn aralıklarında devrededir. 

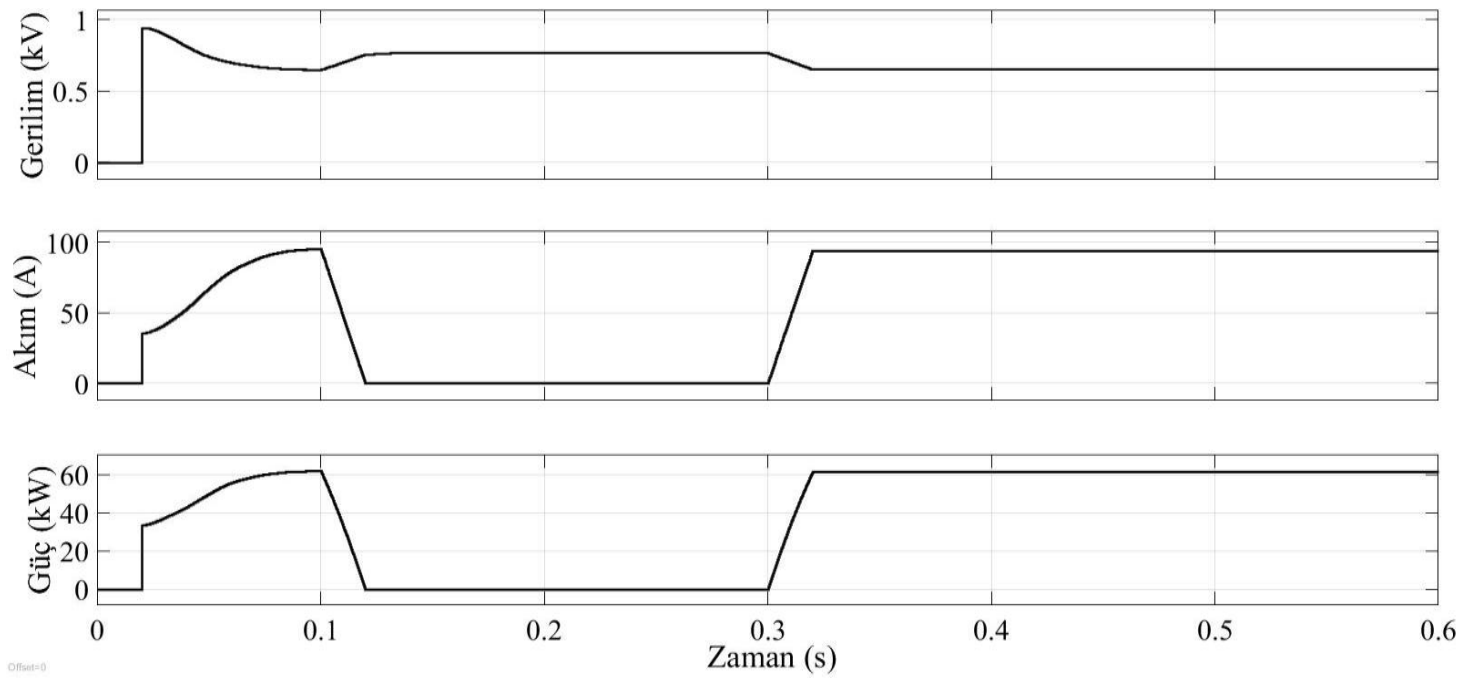

Şekil 14. Yakıt pillerine ait akım, gerilim ve güç değişimleri.

Şekil 15'te beş seviyeli STATCOM cihazının bir fazının her bir H-köprü çıkış gerilimleri ile iki H-köprü gerilimlerinin toplamı alt alta görülmektedir. Burada beş seviye net bir şekilde görülmektedir.

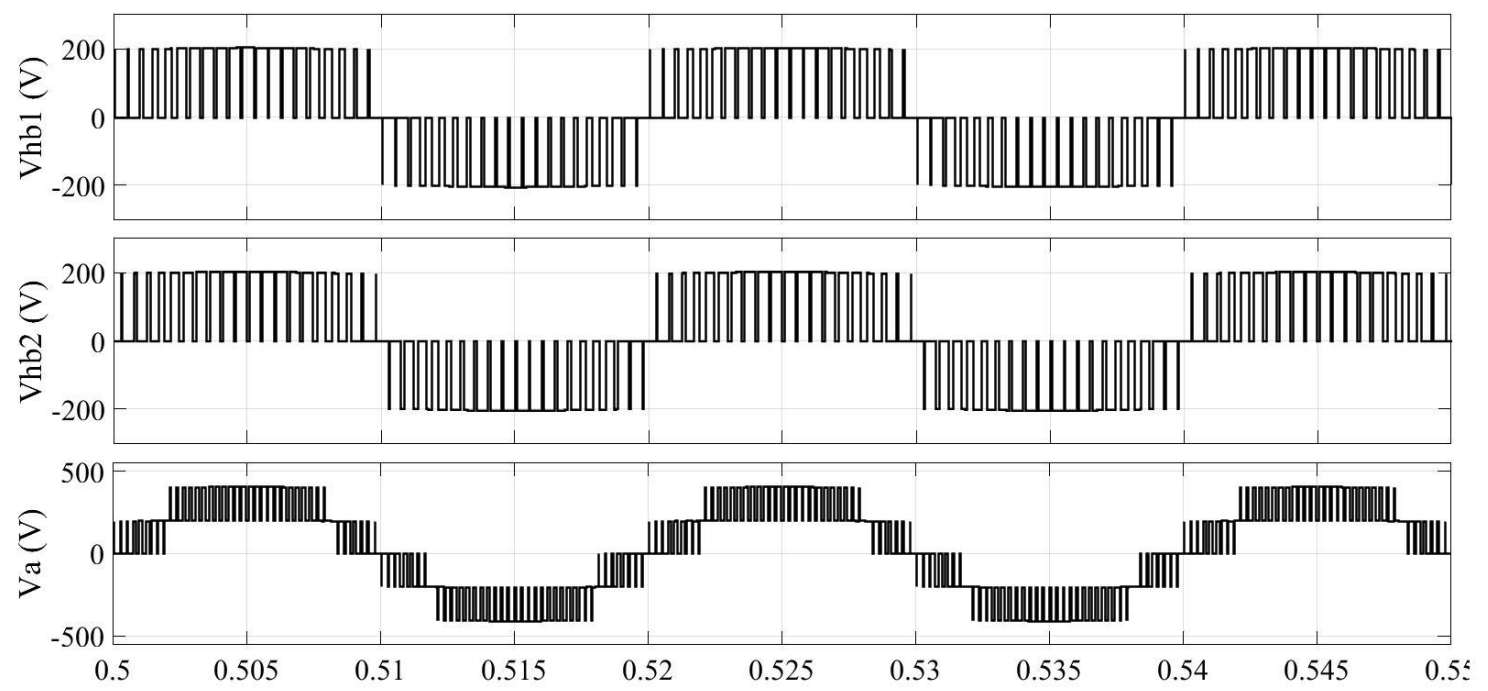

Şekil 15. STATCOM evirici çıkışının bir fazının gerilim değişimi.

Şekil 16 ve 17'de STATCOM devrede iken ortak bağlantı noktasındaki gerilim ve akımın değişimini göstermektedir. Artık akım ile gerilim arasında faz farkının olmadığı net bir şekilde görülmektedir. STATCOM bu kaymayı düzeltmiştir. 


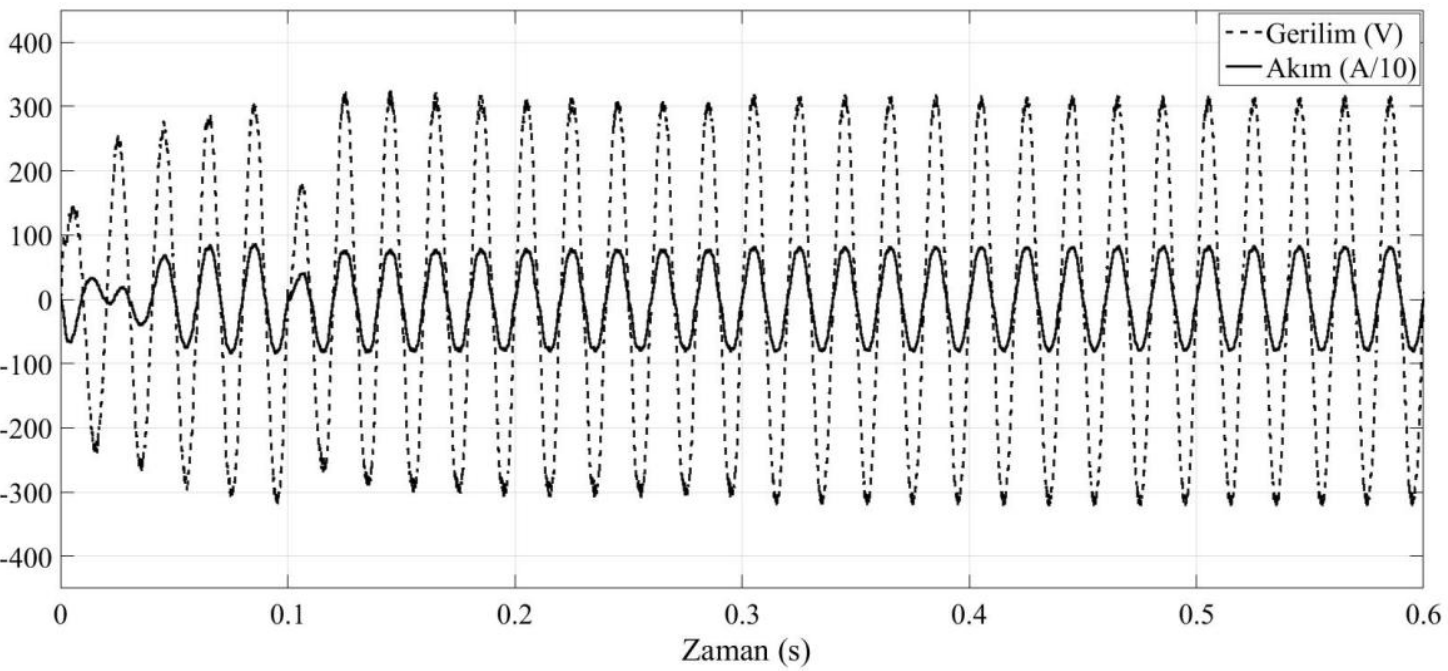

Şekil 16. STATCOM devredeyken ortak bağlantı noktasındaki akım ve gerilimin değişimi.

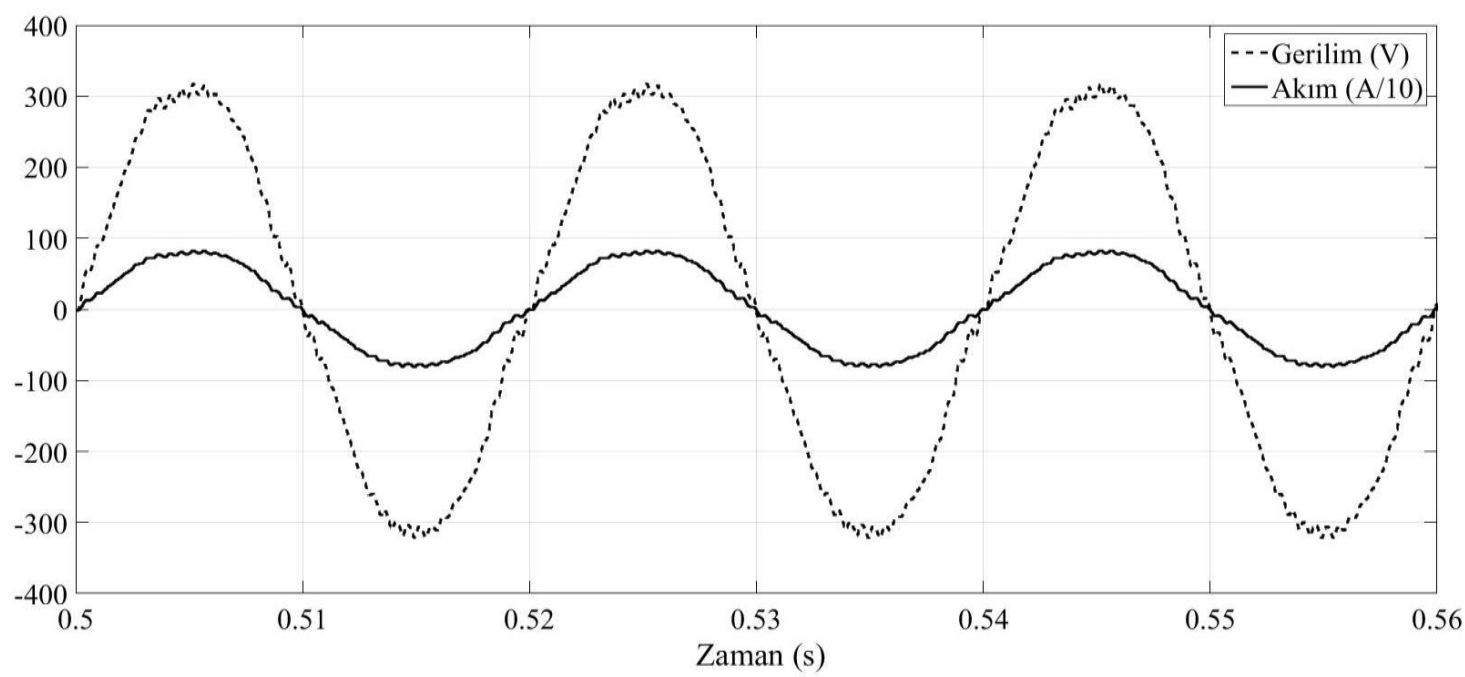

Şekil 17. STATCOM devredeyken ortak bağlantı noktası akım ve gerilim değişiminin ayrıntılı çizimi.

Şekil 18'de STATCOM devredeyken sistemdeki istenmeyen reaktif gücün tamamen elimine edildiği görülmektedir. BMD’li denetleyici bu görevi düzgün bir şekilde başarmaktadır. 


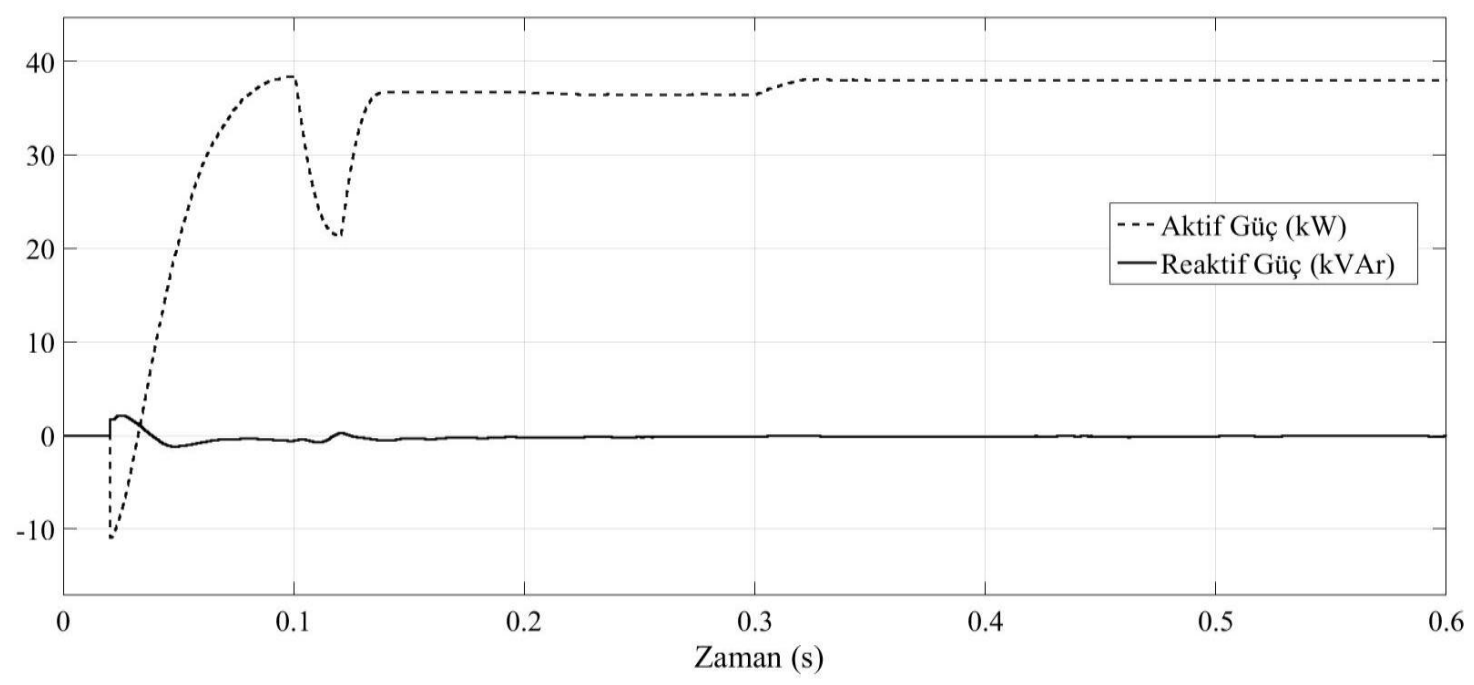

Şekil 18. STATCOM devredeyken ortak bağlantı noktasındaki aktif ve reaktif güç değişimleri.

Şekil 19'da yükler üzerindeki gerilimin etkin değerinin değişimi görülmektedir. Yük gerilimi $380 \mathrm{~V}$ civarında değişmektedir.

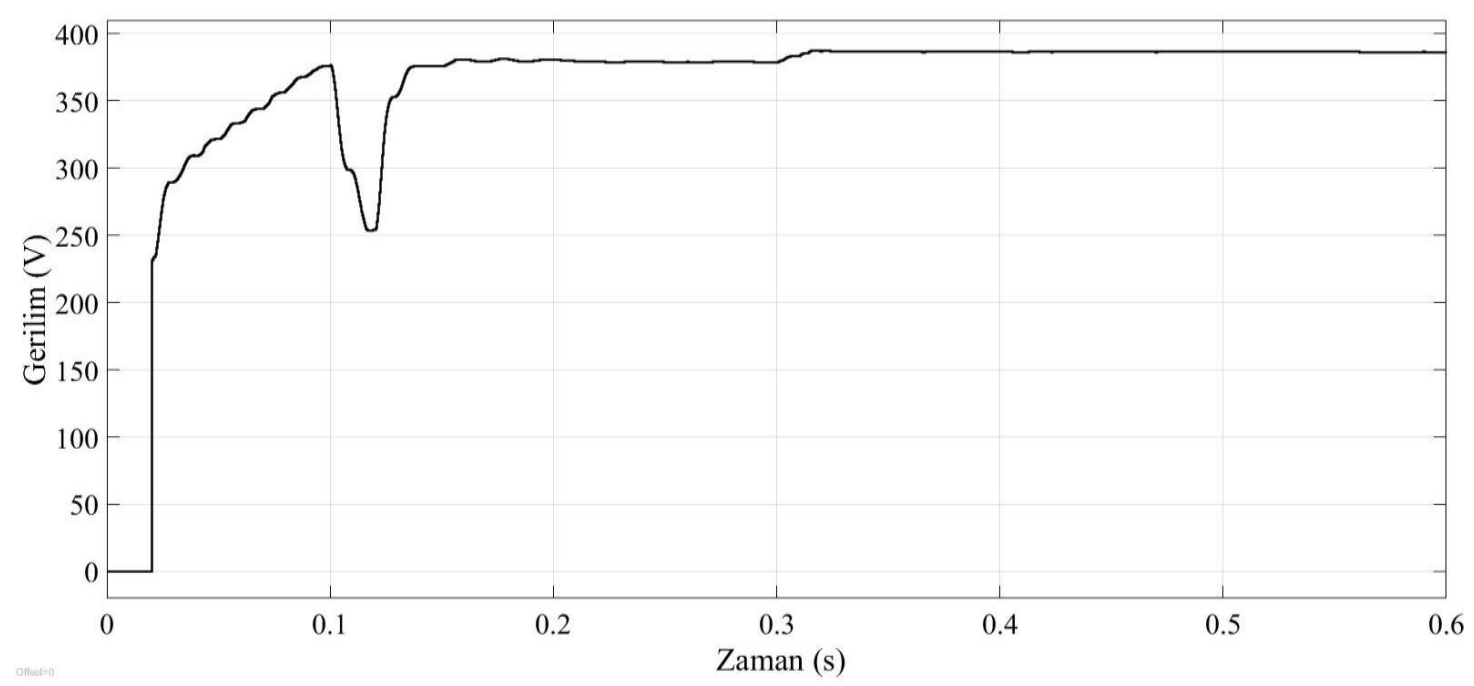

Şekil 19. Yükler üzerindeki gerilimin değişimi.

Şekil 20'de yükler üzerindeki THD değeri görülmektedir. Burada görüldüğü gibi yük üzerindeki akımın THD değeri istenilen değer olan \%5'in altında kalmıştır. 


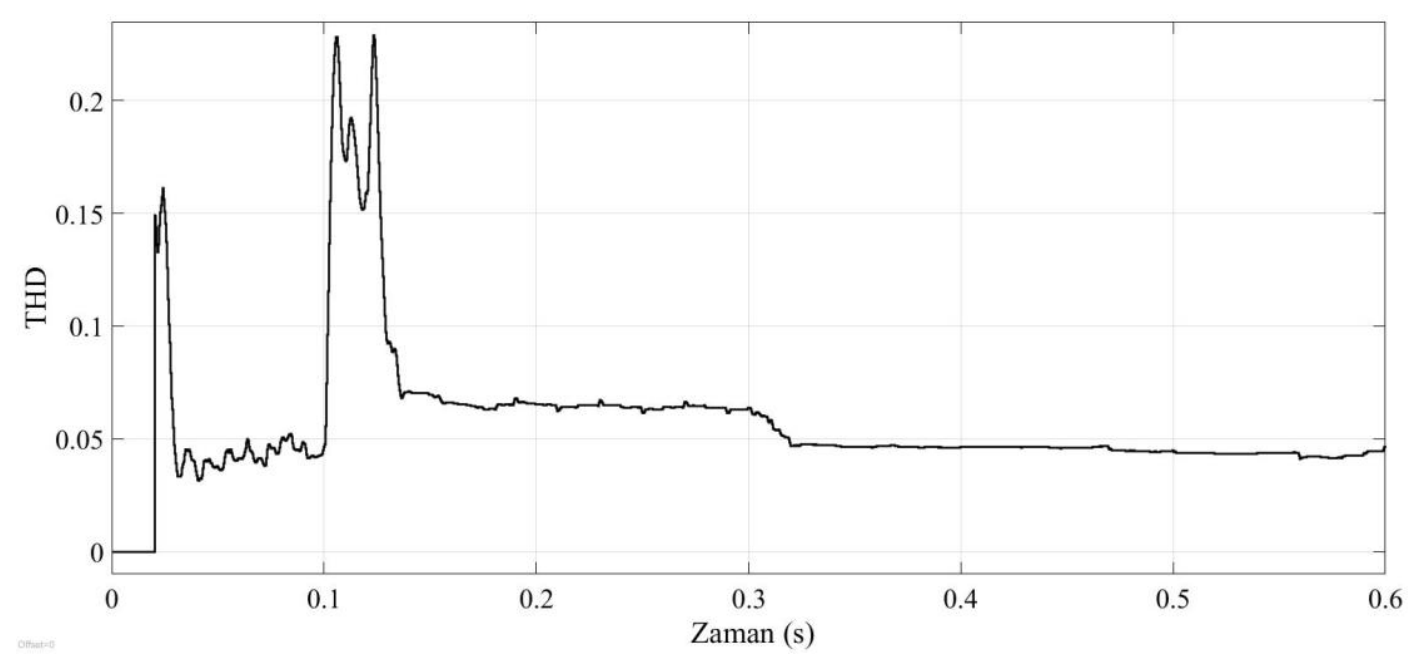

Şekil 20. Yükler üzerindeki THD değiş̧imi.

Tüm bu benzetim çalışmaları sonucunda STATCOM devredeyken ana hattan reaktif güç çekilmediği görülmektedir. Aktif güçte ise bir değişiklik yoktur. Sistem gerilimi istenilen seviyede tutulabilmiştir ve gerilim ve akımdaki bozulmalar da en aza indirilmiştir. Bu sonuçlar da STATCOM cihazının bu sistem için başarılı bir şekilde görevini yaptığını göstermektedir.

\section{Teşekkür}

Bu çalışma, TÜBİTAK-114E474 No.lu "Küçük Ölçekli Rüzgar Türbinlerinde Yeni Ve Akıllı Bir STATCOM Tasarımı Ve Uygulaması” isimli proje kapsamında yürütülmüştür. Yazarlar, sağlanan destekten dolayı TÜBİTAK'a teşekkür ederler.

\section{Kaynaklar}

Altaş, I. H. ve Sharaf, A. M., 2007. A Generalized Direct Approach for Designing Fuzzy Logic Controllers in Matlab/Simulink GUI Environment. International Journal of Information Technology and Intelligent Computing, Int. J. IT \&IC, (4),1.

Gultekin, B. ve Ermis, M., 2013. Cascaded Multilevel Converter-Based Transmission STATCOM System Design Methodology and Development of a $12 \mathrm{kV} \pm 12$ MVAr Power Stage. IEEE Transactions on Power Electronics, (28),11: 4930-4950.

Hingorani, N. G. ve Gyugyi, L., 2000. Understanding FACTS, IEEE Press, USA.

Mengi, O. Ö. ve Altaş, İ. H., 2008. Fotovoltaik ve Yakıt Hücreli Karma Temiz Enerji Sisteminin Modellenmesi ve Simülasyonu. Ulusal Temiz Enerji Günleri (UTEG 2008), 683-690.

Mengi, O. Ö. ve Altaş, İ. H., 2012. Fuzzy Logic Control for a Wind/Battery Renewable Energy Production System. Turk J Elec Eng \& Comp Sci, 20, 2:187-206.

Quasching, V., 2005. Understanding Renewable Energy Systems. Earthscan Company, England.

Ross, Timoty J., 2004. Fuzzy Logic with Engineering Applications 2e, John Wiley and Sons.

Singh, B., Saha, R., Chandra, A. ve Al-Haddad, K., 2009. Static Synchronous Compensators (STATCOM): a Review. IET Power Electron, (2),4: 297-324. 